\title{
Detection of contradictions by linguistically gifted younger students: features of frustration and creativity
}

\author{
Alla Belousova $^{1 *}$, Yulia Mochalova $^{1}$, Ljupco Kevereski ${ }^{2}$, Olga Block $^{3}$ \\ ${ }^{1}$ Don State Technical University, Faculty "Psychology, Pedagogy and Defectology", \\ 344000 Rostov-on-Don, Russian Federation \\ ${ }^{2}$ University “St. Kliment Ohridski” - Bitola, Faclty of Education, Bitola, Republic of \\ Macedonia \\ ${ }^{3}$ Karaganda State University named after E.A. Buketova, Karaganda, Kazakhstan
}

\begin{abstract}
The article presents an analysis of the results of an empirical study aimed at studying the ability to detect contradictions by younger students and the role of frustration and creativity in this process. Two groups of schoolchildren took part in the study: from a specialized English school that were identified as linguistically gifted (27 people, Rostov-onDon), and from a municipal comprehensive school (27 people, Novocherkassk). In the study the following methods were used: V.E. Klochko aimed at determining the ability to detect contradictions, a brief test of creativity of E.P. Torrens and a children's version of the Rosenzweig technique. The study obtained results demonstrating among linguistically gifted elementary school students: higher results in the development of the ability to detect contradictions, as well as the presence of pronounced differences in the development of measures of individual adaptation to their social environment (OSK), the dominance of self-protective reactions (ED), impunitive (M) and extrapunitive (E). A correlated interrelation was found between the ability to detect contradictions, originality, directionality of frustration reactions (M), (I) and the degree of social adaptation (GCR).
\end{abstract}

\section{Introduction}

The effectiveness of solving problems is largely determined by the development of the ability to detect contradictions as one of the cognitive indicators of a person's creative giftedness. Studies (V.E. Klochko [1]; N. Schwarz \& I. Skurnik [2]; N. Stein, M. Hernandez \& T. Trabasso [3]; O.K. Tikhomirov [4]) showed that emotional processes are inextricably linked to problem solving. In the process of solving problems or tasks, a person can experience various emotional states, frustration, anxiety, aggression, anger, or with contradictions, misconceptions and cognitive dissonance (C. Dweck [5]; J. Klein, Y. Moon,

\footnotetext{
*Corresponding author: belousovaak@gmail.com
} 
\& R. Picard [6]). Since the S. Rosenzweig's time, frustration has been understood as a mental state based on experiencing difficulty or the alleged impossibility of achieving a goal [7].

In Russia, one of the first scientists who paid attention to the connection between frustration and thinking was O.K. Tikhomirov, noting the presence of "intellectual frustration" in mental activity [4]. In the studies of Y.E. Kukina, conducted among students, the relationship of reactions to frustration with various types of avoiding solving problems when students discover contradictions is showed [8].

In this regard, it seems important to develop students' tolerance to frustration as adequate reaction to frustration. S. Rosenzweig defines tolerance to frustration as the ability of people to withstand the situation, implementing adequate behavior and psychological adaptation. It was also shown that tolerance to frustration is associated with normal cognitive development [7].

In the studies of S. D'Mello \& A. Graesser [9] it was shown that when students discover new or conflicting information, students may get stuck on a contradiction. Such fixation on the contradiction leads to the inability to overcome the obstacle and solve the problem. Although the authors emphasize that such a stuck can lead to the use of various heuristics that lead to a solution. S.M. Mohsin discovered the effect of frustration on problem-solving behavior by showing that repeated failure experiences give rise to frustration [10]. Studies of $\mathrm{N}$. Harrington showed a relationship between frustration and procrastination of learning tasks, as well as a correlation of frustration with behavior of avoidance [11].

The study of the ability to detect contradictions in the process of thinking was carried out by M. Wertheimer, D. Guilford, V.E. Shred, J. Piaget, S.L. Rubinstein, L. Sekey, E.P. Torrance, O.K. Tikhomirov. Studies of the ability to detect contradictions by preschool children have revealed that preschoolers are characterized by insensibility to contradictions [12].

O.K. Tikhomirov investigated the significance of cognitive contradictions in the initiation of mental activity, which is associated with the first stage in the formation of the goal and the formation of assumptions and hypotheses on its basis [4]. V.E. Klochko tried to study the role of emotional evaluations in the process of goal-setting, in the transition from non-thoughtful activity to the actual mental one. V.E. Klochko showed that, under the conditions of a direct instruction to search for a contradiction, participants found contradictions [1].

N.E. Veraksa suggested that controvesial problem situations appear as conditions that stimulate the child's reflective mental activity. Conflicting problem situations are characterized by the following conditions: the same object at different points in time has conflicting, mutually exclusive properties. Among children, during the process of observing such objects, conflicting, mutually exclusive ideas about their properties were formed. In his studies, children tried to relate and link these ideas with each other. They actively searched for the reason underlying these conflicting properties of objects. According to the results of the experiments, it was concluded that a certain level of development of figurative anticipation of children acts as a condition for the emergence of controversial problem situations. According to N.E. Veraksa, a necessary condition for the formation of a creative position is the creation of a contradictory, conflict situation that would encourage the child to intervene personally in events [13].

O.N. Kozyreva investigated the creative position of preschoolers and the psychological conditions of its formation. At the same time, she suggested that the creative position of the preschooler is formed in a situation of resolving the contradictions presented on subjectively significant social plot-figurative material. She created similar conditions in games with contradictions, which make it possible to find many options for non-standard solutions and at the same time show her personal emotional inclusion. Mastering the 
intellectual methods of resolving contradictions is a cognitive component of the development of a creative position [14].

In the concept of giftedness E.P. Torrance singles out sensitivity to problems, detection and formulation of problems, generation of hypotheses on how to solve problems, their verification, finding solutions and interpretation of results [15].

J. Renzulli emphasizes that giftedness includes: intelligence which is above average one; perseverance motivation, as involvement in the task involves volitional efforts; creative approach or creativity, defined through fluency, flexibility and originality of thinking, openness to new experience, curiosity, risk and sensitivity [16].

Thus, the studies emphasize the relationship of thinking and emotions, the influence of frustration as an emotional state on problem solving. The study of creative thinking in the structure of giftedness shows the role of the ability to detect contradictions as a factor of giftedness.

The presented positions allowed us to formulate hypotheses: 1. children with pronounced giftedness have higher indicators of the ability to detect contradictions, creativity and can differ in the severity of reactions to frustration; 2 . There are relationships between indicators of the ability to detect contradictions, creativity, direction and type of reactions to frustration.

\section{Materials and Methods}

The aim of our work is to investigate the ability to detect contradictions, creativity and frustration by gifted children of primary school age, as well as the relationship of the ability to detect contradictions, creativity with frustration reactions.

Participants. Our study was conducted in two schools: in the secondary school Number 24, Novocherkassk, Rostov Region (1st group) and the secondary school Number 34, Rostov-on-Don (2nd group). The study involved 54 students of class four at the age of 10 years. The School Number 34 of Rostov-on-Don specializes in the study of English; children are selected for admission to the school. We can say that children in this school have a pronounced linguistic talent. Thr School Number 24 of Novocherkassk is a municipal comprehensive school, in which children from a nearby district study.

Measures. In our work the author's technique V. E. Klochko directed on detection of contradictions by children of primary school age was used [1]; a short test of determining the creativity of E.P. Torrens [17]; children's version of the test "Picturesque Frustration" by S. Rosenzweig [18]. For quantitative processing of the results, statistical methods were used: the Mann-Whitney method in order to check the significance of differences, the Spearman rank correlation method in order to obtain information about the relationship between creativity and frustration reactions of schoolchildren. Standard computer programs for statistical data analysis were used for data processing: SPSS 17.0 for Windows.

\section{Discussions}

An analysis of the data carried out using the methods of mathematical statistics showed that there are pronounced differences in the development of the studied indicators. First of all, it was found that the ability to detect contradictions is better developed among younger students with linguistic giftedness who are from a specialized school. Younger students from the municipal school do not show high achievements in detecting contradictions, 
gifted peers from a specialized school for studying English are ahead of them (differences are significant, $\mathrm{U}=62.0, \mathrm{p}=0,000)$.

According to the Torrens' test, in both groups of schoolchildren there is the same tendency in the severity of creativity indicators: elaboration dominates, fluency is in second place (the values in both groups are the same), originality is in third, and flexibility is in the third place. There is a tendency for a difference between the severity of the "elaboration" indicator among schoolchildren of the first and second groups: schoolchildren of the first group (from the municipal school) are ahead of their gifted peers in the development of detailed drawings, behind which there is a detailed thinking (differences are significant, $\mathrm{U}$ $=248.5, \mathrm{p}=0.045)($ Table 1$)$.

Table 1. Average values of the ability to detect contradictions, indicators according to the tests of Torrens and Rosenzweig of gifted children and primary school students from a municipal school

\begin{tabular}{|c|c|c|c|c|c|c|c|c|c|c|c|c|}
\hline \multirow[b]{2}{*}{ Group } & \multirow[b]{2}{*}{$\begin{array}{l}\text { The } \\
\text { ability } \\
\text { to detect } \\
\text { contradi } \\
\text { ctions }\end{array}$} & \multicolumn{4}{|c|}{ Test E.P. Torrens } & \multicolumn{7}{|c|}{ Test S. Rosenzweig } \\
\hline & & $\begin{array}{l}\text { Orig } \\
\text { inali } \\
\text { ty }\end{array}$ & $\begin{array}{l}\text { Flue } \\
\text { ncy }\end{array}$ & $\begin{array}{l}\text { Flexi } \\
\text { bility }\end{array}$ & $\begin{array}{l}\text { Elabor } \\
\text { ation }\end{array}$ & $\mathrm{E}$ & I & $\mathrm{M}$ & $\begin{array}{l}\mathrm{O} \\
\mathrm{D}\end{array}$ & ED & NP & $\begin{array}{l}\mathrm{GC} \\
\mathrm{R}\end{array}$ \\
\hline 1 & 26,0 & 9,8 & 10,0 & 8,5 & 33,9 & 5,8 & $\begin{array}{l}11, \\
4\end{array}$ & 6,4 & 4,7 & 7,0 & $\begin{array}{l}12, \\
0\end{array}$ & 3,0 \\
\hline 2 & 29,2 & 11,1 & 10,0 & 8,2 & 26,4 & 7,2 & 8,1 & 8,5 & 5,5 & 9,3 & 9,1 & 4,7 \\
\hline $\begin{array}{l}\text { Mann- } \\
\text { Whitney } \\
\text { test }\end{array}$ & 62,0 & $\begin{array}{l}272, \\
5\end{array}$ & $\begin{array}{l}351, \\
0\end{array}$ & $\begin{array}{l}302, \\
5\end{array}$ & 248,5 & $\begin{array}{l}24 \\
6,5\end{array}$ & $\begin{array}{l}12 \\
5,0\end{array}$ & $\begin{array}{l}16 \\
7,5\end{array}$ & $\begin{array}{l}29 \\
8,5\end{array}$ & $\begin{array}{l}21 \\
5,5\end{array}$ & $\begin{array}{l}22 \\
4,0\end{array}$ & $\begin{array}{l}10 \\
2,0\end{array}$ \\
\hline $\begin{array}{l}\text { Asymp. } \\
\text { Sig. (2- } \\
\text { Tailed) }\end{array}$ & 000 & ,107 & 317 & 233 & 045 & $\begin{array}{l}, 04 \\
0\end{array}$ & $\begin{array}{l}, 00 \\
0\end{array}$ & $\begin{array}{l}, 00 \\
1\end{array}$ & $\begin{array}{l}, 25 \\
0\end{array}$ & $\begin{array}{l}\text {,01 } \\
0\end{array}$ & $\begin{array}{l}01 \\
5\end{array}$ & $\begin{array}{l}, 00 \\
0\end{array}$ \\
\hline
\end{tabular}

The results of data analysis by the method of $\mathrm{S}$. Rosenzweig are even more demonstrative.

First of all, we can immediately note that gifted students from a specialized school show better results in developing measures of individual adaptation to their social environment (differences are significant, $U=215.5, \mathrm{p}=0.010$ ). Gifted younger schoolchildren show the dominance of self-protective reactions ED, the type of reaction is "with fixation on selfdefense" (the differences are significant, $U=102.0, p=0.010$ ), as well as the dominance in the direction of reactions: $\mathrm{M}$ - impressive (the differences are significant, $\mathrm{U}=167.5 .0, \mathrm{p}=$ 0.001 ) and $\mathrm{E}$ are extrapunitive (there is the tendency to significance of differences, $\mathrm{U}=$ $246.5, \mathrm{p}=0.040)$.

Among schoolchildren from the municipal school there is the dominance of the type of NP reactions "fixed with satisfaction of needs" (the differences are significant, $U=224.0, p$ $=0.015)$ and there is also the dominance in the direction of reactions, it is I-intro-punitive (differences are significant, $\mathrm{U}=125.0, \mathrm{p}=0.000$ ).

Thus, it can be said that for schoolchildren from the municipal school, the reactions of adequate response aimed at resolving conflicting, frustrating situations, with the dominance of acceptance of responsibility and guilt for the frustrating situation, are dominant. At the same time, gifted students from a specialized school are characterized by fixation on frustration, the development of a self-protective reaction. Thus, there are differences in the peculiarities of the action in frustrating situations between gifted schoolchildren and schoolchildren from municipal schools. Gifted students perceive frustrating situations as alarming ones, which will pass themselves (M) or they hyperbolize frustrating situations, forming the need for solving problems by third parties (E). This orientation of reactions is combined with the type of reaction (ED), in which the child in every possible way tries to get away from the decision, protects his "I". It can be assumed that in the conditions of the 
school educational environment, certain requirements for a gifted child are formed, suggesting his high intellectual level. Gifted younger students may be afraid of impossibility to meet these expectations from teachers, parents and lose their identity as a gifted child, and the general perfectionism of gifted children can contribute to the formation of such reactions as unwillingness to solve problems where they cannot solve them. This is consistent with the ideas of D. Lovecky, who points at common emotional features that are characteristic for gifted children, for example, increased sensitivity, emotional intensity and reactivity, a variety of emotions, perfectionism and uneven development of intellectual and emotional abilities. It also refers to M.M. Piechowski, who highlights the emotional characteristics that are important for the development of children's potential: emotional tension, sensitivity, empathy and compassion [19].

For younger schoolchildren from the municipal school, frustrating situations do not mean checking their intelligence, talent, they are just ordinary life situations and, perhaps, therefore, children are directed to solving the situation (NP) and take responsibility (I).

The next step in our analysis was the study of the relationship between the ability to detect contradictions, creativity, focus and the type of frustration reactions among primary school students. The results are presented in table 2 .

Table 2. Relationships of the ability to detect contradictions with creativity and frustration reactions

\begin{tabular}{|l|l|l|l|l|}
\hline Indicators & GCR & I & M & Originality \\
\hline $\begin{array}{l}\text { The ability to } \\
\text { detect } \\
\text { contradictions }\end{array}$ & $0,554^{* *}$ & $-0,338^{* *}$ & $0,360 * *$ & $0,352^{* *}$ \\
\hline
\end{tabular}

The analysis of the data presented in table 2 allows us to talk about the fact, that in primary school age there is a presence of the relationship between the ability to detect contradictions and originality, i.e. the ability to produce ideas other than obvious ones. Also, the ability to detect contradictions is negatively related to the intrapunitive reaction (I - the direction of frustration towards oneself), but positively related to the impusive orientation of human reactions (M), in which frustrating situations are considered as something insignificant and surmountable, and a measure of individual adaptation person to the social environment.

Our results are consistent with the provisions of D. Renzulli [16], E.P. Torrens [15], M.A. Wallach [20], who showed the presence of a relationship between intelligence, creativity and adaptation to external conditions: children with a high level of intelligence and creativity demonstrate initiative and successfully adapt to the external environment; children with a low level of intelligence and creativity poorly adapt to the external environment. In our studies a relationship was revealed between the ability to detect contradictions by preschool children with indicators of creativity: originality, fluency, flexibility and sophistication [21, 22].

\section{Conclusion}

As it was shown, linguistically gifted younger students studying in a specialized English school have a better developed ability to detect contradictions, higher results are observed in the development of measures of individual adaptation to their social environment (OSK), self-protective reactions dominate (type of reaction ED - "with fixation on self-defense"), as well as impunitive (M) and extrapunitive (E). 
Thus, gifted younger schoolchildren have some features of emotional reactions to frustration, which can be interpreted as a manifestation of the mechanism of emotional regulation in a situation of detection of contradictions.

The relationship between the ability to detect contradictions, originality, directionality of frustration reactions (M), (I) and the degree of social adaptation (GCR) was also revealed.

The obtained results show that the ability to detect contradictions involves a further deepening of empirical and theoretical research on the study of emotional factors, in particular, the role of frustration in the development of creative thinking among gifted children.

\section{References}

1. V.E. Klochko, E.V. Galazhinskiy, Samoregulyatsiya lichnosti: sistemnyy vzglyad, (Tomsk, 2000)

2. N. Schwarz, \& I. Skurnik, The Psychology of Problem Solving (Cambridge University Press, New York, 2003)

3. N. Stein, M. Hernandez \& T. Trabasso, Handbook of emotions (Guilford Press, New York, 2008)

4. O.K. Tikhomirov, Psikhologiya myshleniya (Akademiya, Moscow, 2002)

5. C. Dweck, Improving academic achievement: Impact of psychological factors on education (Academic Press, Orlando, 2002)

6. J. Klein, Y. Moon, \& R. Picard, Interacting with Computers, 14(2), 119-140, (2002)

7. S. Rosenzweig, Personality and Behaviour Disorders (New York, 1944)

8. Yu.Ye. Kukina, Proyavleniye tipologicheskikh kharakteristik frustratsionnogo reagirovaniya lichnosti v myslitel'noy deyatel'nosti (Barnaul, 2000)

9. S. D'Mello \& A. Graesser, Proceedings of the 32nd Annual Cognitive Science Society, 2721-2726, (Cognitive Science Society, Austin, 2010)

10. S.M. Mohsin, J. of Abnormal and Social Psychology, 49(1), 152, (1954)

11. N. Harrington, Clinical Psychology \& Psychotherapy, 12(5), 374-387, (2005)

12. ZH. Piazhe, Rech' i myshleniye rebenka, (Pedagogika-Press, Moscow, 1999)

13. N.Ye. Veraksa, A.I. Bulycheva, Voprosy psikhologii, 6, 26- 34, (2003)

14. N.A. Kozyreva, Voprosy psikhologii, 2, 80- 91, (2007)

15. E.P. Torrance, Torrance Tests of Creative Thinking: Norms-technical manual (Ginn., Lexington, 1974)

16. J. Renzulli, Conception of giftedness (Cambridge University Press, New-York, 1986)

17. Kratkiy test tvorcheskogo myshleniya. Figurnaya forma: posobiye dlya shkol'nykh psikhologov (INTOR, Moskva,1995)

18. Diagnostika emotsional'no-nravstvennogo razvitiya (Piter, St. Petersburg, 2002)

19. D. Lovecky, Roeper Review, 15 (1), 18-25, (1992)

20. M.A. Wallach, The creativity-intelligence distinction (General Learning Press, New York, 1971)

21. A. Belousova, G. Kozhukhar, L. Ryumshina, 8th International Conference of Education, Research and Innovation, 4061-4067, (IATED, Seville, 2015)

22. A. Belousova, G. Kozhukhar, V. Pishchik, 2019 the 4th International Conference on Education Science and Development, 38-43, (ICESD, Shenzhen, 2019) 